\title{
Working Capital Management in Blue Bharath Exim Pvt.Ltd, Chennai
}

\author{
Magdalene Peter, S.Fabiyola Kavitha
}

\begin{abstract}
Working capital is the distinction between current resources and current liabilities, which is a piece of capital that needn't to satisfy for the time being. That is, working capital mirrors the overall security of short-term capital. We can be educated on the endeavor's money related hazard, by the benefit of working capital and some related pointers. By and large, the additionally working capital endeavors possess, the less budgetary hazard they may confront. Be that as it may, an excessive amount of working capital isn't reasonable for the undertakings who wish a long-term advancement, as the lost benefit. We propose to improve the working capital administration, for its significance and money related vigor. Notwithstanding, there are seldom looks into associated with developing a working capital administration framework. [1],[ 3],[5] To consummate the administration procedure, we propose an effective working capital administration framework on execution, which might be a changing cycle. We would like to give a reference to the future research and the board rehearses Keywords : management,capital,investment
\end{abstract}

\section{INTRODUCTION}

In budgetary administration, two significant choices are extremely imperative and critical. They are choice with respect to fixed resources/fixed capital and choice regardingworking capital/current resources. Both are significant and a firm consistently analyzestheir impact to conclusive effect upon benefit and risk.Fixed capital alludes to the assets put resources into such fixed or changeless resources asland, building, and apparatus and so on. Though working capital alludes to the fundslocked up in materials, work in advancement, completed products, receivables, andcash and so on. [2 ],[ 4],[6]

In this manner, in basic words, working capital might be characterized as "capitalinvested in current resources." Here current resources are those benefits, whichcan be changed over into money inside a brief timeframe and the money receivedis again put into these advantages. In this way, it is continually accepting orcirculating. Henceforth, working capital is otherwise called circling capital orfloating capital. Working capital assumes a significant job in the everyday exercises of a business venture. The working capital administration personally interfaces the working of each office in the business concern. On the off chance that

Revised Manuscript Received on July 22, 2019.

Magdalene Peter, Department of MBA, Bharath Institute of Higher Education and Research, Tamilnadu, India. Email: magdalene.bsb@gmail.com

Fabiyola Kavitha, Department of MBA, Bharath Institute of Higher Education and Research, Tamilnadu, India. Email: fabiyolakavitha@gmail.com working capital is bungled, it might influence the presence of the business itself. In such units the creation of money in the present resources would be high, yet the business may confront the deficiency of stock. On the off chance that the blocked assets in current resources are not appropriately used at the correct time for the buy of stock, it won't just build the benefit acquiring limit of the firm yet in addition lessen the hazard. Correspondingly, current liabilities should keep in such an extent, that present resources can be changed over into money to pay for it during the time of dissolvability emergency

\section{A. CONCEPT OF WORKING CAPITAL}

There are two ideas of working capital:

\section{- Quantitative \\ - Qualitative.}

A few people likewise characterize the two ideas as gross working idea and systems administration idea. [8],[ 10] ,[12]

As indicated by quantitative idea, the measure of working capital alludes to 'aggregate of current resources'. What we call current resources? Smith called, 'circulatingcapital'. Current resources are viewed as gross working capital in this concept."The gross working capital is the capital put resources into the all out current resources of the ventures".

The subjective idea gives a thought with respect to wellspring of financing capital. As per subjective idea the measure of working capital alludes to "overabundance ofcurrent resources over current liabilities." L.J. Guttmann characterized working capital as "the part of a company's present resources which are financed from long haul funds."The overabundance of current resources over current liabilities is named as 'Net working capital'. [7],[9] ,[11]

Net working capital $=$ current resources - current liabilities

\section{METHOD OF DATA COLLECTION}

The information for the examination is gathered from optional sources. The investigation is essentially limited to auxiliary information got from the yearly report of the organization, books of records, periodicals, and so on the optional information was gathered from the yearly reports of the organization from 2012 to 2016. [13], [15] ,[ 17]

\section{A. SATISTICAL TOOLS USED}

- Working capital
Analysis
- Ratio analysis


Working Capital Management in Blue Bharath Exim Pvt.Ltd, Chennai

\section{B. LIMITATIONS OF THE STUDY}

The limitations of the study are;

- The precision of the aftereffect of the investigation will relies on the exactness of information given by the organization.

- The study covers just the time of 5 (2012 to 2016)

- Usually no business will uncover its each business data so accessibility of the information is restricted. [14],[16], [18]

Table:1

\# TABLE 4.1.1 SCHEDULE OF CHANGES IN WORKING CAPITAL (2012)

\begin{tabular}{|l|l|l|l|l|}
\hline PARTICULARS & $\begin{array}{l}2012 \\
\text { AMOUNT } \\
\text { Rs. }\end{array}$ & $\begin{array}{l}\mathbf{2 0 1 3} \\
\text { AMOUNT } \\
\text { Rs. }\end{array}$ & $\begin{array}{l}\text { INCREASE } \\
\text { AMOUNT } \\
\text { Rs. }\end{array}$ & $\begin{array}{l}\text { DECREASE } \\
\text { AMOUNT } \\
\text { Rs. }\end{array}$ \\
\hline ASSETS & & & & \\
\hline $\begin{array}{l}\text { CURRENT } \\
\text { ASSETS }\end{array}$ & & 825100 & 574160 & - \\
\hline $\begin{array}{l}\text { Inventory (ERP } \\
\text { Software } \\
\text { license) }\end{array}$ & 250940 & 1590440 & 327010 & \\
\hline Sundry Debtors & 1263430 & 58400 & - & 1532040 \\
\hline $\begin{array}{l}\text { Cash and Bank } \\
\text { Balance }\end{array}$ & 1590440 & 3686400 & 1399650 & \\
\hline $\begin{array}{l}\text { Loans and } \\
\text { Advances }\end{array}$ & 2286750 & 13730 & - & 920 \\
\hline Prepaid & 14650 & & & \\
\hline
\end{tabular}

\begin{tabular}{|l|l|l|l|l|}
\hline Expenses & & & & \\
\hline Accrued Income & 59090 & 42925 & & 16165 \\
\hline $\begin{array}{l}\text { TOTAL } \\
\text { CURRENT } \\
\text { ASSETS }\end{array}$ & 5465300 & 6204638 & 2300820 & 1549125 \\
\hline LESS & & & & \\
\hline $\begin{array}{l}\text { CURRENT } \\
\text { LIABILITIES }\end{array}$ & & 6910610 & - & 457295 \\
\hline $\begin{array}{l}\text { Sundry } \\
\text { Creditors }\end{array}$ & 6453315 & 6910610 & - & 457295 \\
\hline $\begin{array}{l}\text { TOTAL } \\
\text { CURRENT } \\
\text { LIABLITIES }\end{array}$ & 6453315 & $\mathbf{2 3 0 0 8 2 0}$ & $\mathbf{1 0 9 1 8 3 0}$ \\
\hline $\begin{array}{l}\text { NET } \\
\text { WORKING } \\
\text { CAPITAL }\end{array}$ & 988015 & $\mathbf{7 0 5 9 7 2}$ & $\mathbf{2 3 0}$ & \\
\hline
\end{tabular}

Table:2
TABLE 4.1.2 SCHEDULE OF CHANGES IN WORKING CAPITAL (2013)

\begin{tabular}{|l|l|l|l|l|}
\hline PARTICULARS & $\begin{array}{l}\mathbf{2 0 1 3} \\
\text { AMOUNT } \\
\text { Rs. }\end{array}$ & $\begin{array}{l}\mathbf{2 0 1 4} \\
\text { AMOUNT } \\
\text { Rs. }\end{array}$ & $\begin{array}{l}\text { INCREASE } \\
\text { AMOUNT } \\
\text { Rs. }\end{array}$ & $\begin{array}{l}\text { DECREASE } \\
\text { AMOUNT } \\
\text { Rs. }\end{array}$ \\
\hline ASSETS & & & & \\
\hline $\begin{array}{l}\text { CURRENT } \\
\text { ASSETS }\end{array}$ & & 542920 & - & 282180 \\
\hline $\begin{array}{l}\text { Inventory (ERP } \\
\text { Softeware } \\
\text { license) }\end{array}$ & 825100 & 3093060 & 1502620 & \\
\hline Sundry Debtors & 1590440 & 605030 & 546630 & \\
\hline $\begin{array}{l}\text { Cash and Bank } \\
\text { Balance }\end{array}$ & 58400 & & & 494169 \\
\hline $\begin{array}{l}\text { Loans and } \\
\text { Advances }\end{array}$ & 3686400 & 3192231 & & \\
\hline Prepaid Expenses & 13730 & 17022 & 3292 & \\
\hline
\end{tabular}

\begin{tabular}{|l|l|l|l|l|}
\hline Accrued Income & 42925 & 96426 & 53501 & \\
\hline $\begin{array}{l}\text { TOTAL } \\
\text { CURRENT } \\
\text { ASSETS }\end{array}$ & 6216995 & 7546689 & 2106043 & 776349 \\
\hline LESS & & & & \\
\hline $\begin{array}{l}\text { CURRENT } \\
\text { LIABILITIES }\end{array}$ & & & & \\
\hline Sundry Creditors & 6910610 & 14642090 & - & 7731480 \\
\hline $\begin{array}{l}\text { TOTAL } \\
\text { CURRENT } \\
\text { LIABLITIES }\end{array}$ & 6910610 & 14642090 & - & 7731480 \\
\hline $\begin{array}{l}\text { NET } \\
\text { WORKING } \\
\text { CAPITAL }\end{array}$ & $\mathbf{7 0 5 9 7 2}$ & $\mathbf{7 0 9 5 4 0 1}$ & $\mathbf{2 1 0 6 0 4 3}$ & 6955131 \\
\hline
\end{tabular}

Table:3

TABLE 4.1.3 SCHEDULE OF CHANGES IN WORKING CAPITAL (2014)

\begin{tabular}{|l|l|l|l|l|}
\hline PARTICULARS & $\begin{array}{l}\mathbf{2 0 1 4} \\
\text { AMOUNT } \\
\text { Rs. }\end{array}$ & $\begin{array}{l}\mathbf{2 0 1 5} \\
\text { AMOUNT } \\
\text { Rs. }\end{array}$ & $\begin{array}{l}\text { INCREASE } \\
\text { AMOUNT } \\
\text { Rs. }\end{array}$ & $\begin{array}{l}\text { DECREASE } \\
\text { AMOUNT } \\
\text { Rs. }\end{array}$ \\
\hline ASSETS & & & & \\
\hline $\begin{array}{l}\text { CURRENT } \\
\text { ASSETS }\end{array}$ & & & & \\
\hline $\begin{array}{l}\text { Inventory (ERP } \\
\text { license) }\end{array}$ & 542920 & 950310 & 407390 & \\
\hline Sundry Debtors & 3093060 & 4431190 & 1338130 & \\
\hline $\begin{array}{l}\text { Cash and Bank } \\
\text { Balance }\end{array}$ & 605030 & 371375 & - & 233655 \\
\hline $\begin{array}{l}\text { Loans and } \\
\text { Advances }\end{array}$ & 3192231 & 3371511 & 179280 & \\
\hline Prepaid Expenses & 17022 & 311020 & 293998 & \\
\hline Accrued Income & 96426 & 236385 & & 73266 \\
\hline $\begin{array}{l}\text { TOTAL } \\
\text { CURRENT } \\
\text { ASSETS }\end{array}$ & 7546689 & 9684951 & 2445183 & 306921 \\
\hline
\end{tabular}




\begin{tabular}{|l|l|l|l|l|}
\hline LESS & & & & \\
\hline $\begin{array}{l}\text { CURRENT } \\
\text { LIABILITIES }\end{array}$ & & & & \\
\hline Sundry Creditors & 14642090 & 9396631 & 5245459 & \\
\hline $\begin{array}{l}\text { TOTAL } \\
\text { CURRENT } \\
\text { LIABLITIES }\end{array}$ & 14642090 & 9396631 & 5245459 & \\
\hline $\begin{array}{l}\text { NET } \\
\text { WORKING } \\
\text { CAPITAL }\end{array}$ & 7095401 & $\mathbf{2 8 8 3 2 0}$ & $\mathbf{2 8 0 0 2 7 6}$ & $\mathbf{3 0 6 9 2 1}$ \\
\hline
\end{tabular}

Table:4

TABLE 4.1.4

SCHEDULE OF CHANGES IN WORKING CAPITAL (2015)

\begin{tabular}{|l|l|l|l|l|}
\hline PARTICULARS & $\begin{array}{l}\mathbf{2 0 1 5} \\
\text { AMOUNT } \\
\text { Rs. }\end{array}$ & $\begin{array}{l}\mathbf{2 0 1 6} \\
\text { AMOUNT } \\
\text { Rs. }\end{array}$ & $\begin{array}{l}\text { INCREASE } \\
\text { AMOUNT } \\
\text { Rs. }\end{array}$ & $\begin{array}{l}\text { DECREASE } \\
\text { AMOUNT } \\
\text { Rs. }\end{array}$ \\
\hline ASSETS & & & & \\
\hline $\begin{array}{l}\text { CURRENT } \\
\text { ASSETS }\end{array}$ & & & & \\
\hline $\begin{array}{l}\text { Inventory (ERP } \\
\text { license) }\end{array}$ & 950310 & 4708450 & 3758140 & - \\
\hline Sundry Debtors & 4431190 & 3066220 & - & 1364970 \\
\hline $\begin{array}{l}\text { Cash and Bank } \\
\text { Balance }\end{array}$ & 371375 & 925410 & 554035 & \\
\hline $\begin{array}{l}\text { Loans and } \\
\text { Advances }\end{array}$ & 3371511 & - & - & 3371511 \\
\hline Advance Tax & 311020 & 589870 & 278850 & - \\
\hline Prepaid Expenses & 23160 & 143770 & 120610 & - \\
\hline Accrued Income & 226385 & 169830 & - & 56555 \\
\hline $\begin{array}{l}\text { TOTAL } \\
\text { CURRENT } \\
\text { ASSETS }\end{array}$ & 9684951 & 9603550 & 4711635 & 4793036 \\
\hline LESS & & & & \\
\hline CURRENT & & & & \\
\hline
\end{tabular}

\begin{tabular}{|l|l|l|l|l|}
\hline LIABILITIES & & & & \\
\hline Sundry Creditors & 9396631 & 6053015 & 3343616 & - \\
\hline $\begin{array}{l}\text { TOTAL } \\
\text { CURRENT } \\
\text { LIABLITIES }\end{array}$ & 9396631 & 6053015 & 3343616 & - \\
\hline $\begin{array}{l}\text { NET } \\
\text { WORKING } \\
\text { CAPITAL }\end{array}$ & $\mathbf{2 8 8 3 2 0}$ & $\mathbf{3 5 5 0 5 3 5}$ & $\mathbf{1 3 6 8 0 1 9}$ & $\mathbf{4 7 9 3 0 3 6}$ \\
\hline
\end{tabular}

TABLE : 5INVENTORY TO SALES RATIO

\begin{tabular}{|l|l|l|l|}
\hline YEAR & $\begin{array}{l}\text { INVENTORY } \\
\text { Rs. }\end{array}$ & $\begin{array}{l}\text { SALES } \\
\text { Rs. }\end{array}$ & RATIO \\
\hline 2012 & 5825100 & 39377300 & 0.15 \\
\hline 2013 & 5429251 & 57364800 & 0.09 \\
\hline 2014 & 3880120 & 63273350 & 0.06 \\
\hline 2015 & 9150310 & 77237255 & 0.11 \\
\hline 2016 & 4708450 & 89967680 & 0.05 \\
\hline
\end{tabular}



Fig:1 INVENTORY TO SALES RATIO
TABLE : 6 WORKING CAPITAL TURNOVER RATIO

\begin{tabular}{|l|l|l|l|}
\hline YEAR & $\begin{array}{l}\text { NET WORKING } \\
\text { CAPITAL } \\
\text { Rs. }\end{array}$ & $\begin{array}{l}\text { CURRENT } \\
\text { LIABLITIES } \\
\text { Rs. }\end{array}$ & RATIO \\
\hline 2012 & 988015 & 6453315 & 0.15 \\
\hline 2013 & 705972 & 6910610 & 0.15 \\
\hline 2014 & 7635431 & 14642090 & 0.52 \\
\hline 2015 & 288320 & 9396631 & 0.03 \\
\hline 2016 & 3550535 & 6053015 & 0.59 \\
\hline
\end{tabular}

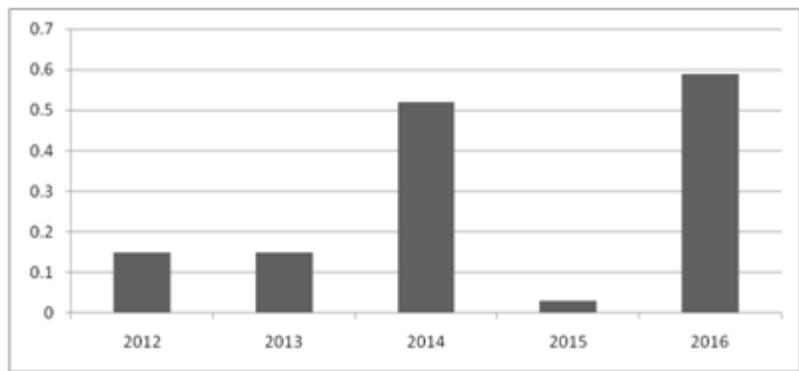

Fig:2 WORKING CAPITAL TURNOVER RATIO

Table:7 INVENTORY TO CURRE NT ASSET RATIO

\begin{tabular}{|l|l|l|l|}
\hline YEAR & $\begin{array}{l}\text { AVERAGE } \\
\text { INVENTORY } \\
\text { Rs. }\end{array}$ & $\begin{array}{l}\text { CURRENT } \\
\text { ASSETS } \\
\text { Rs. }\end{array}$ & RATIO \\
\hline 2012 & 5825100 & 5465300 & 1.06 \\
\hline 2013 & 5429251 & 6204638 & 0.12 \\
\hline 2014 & 3880120 & 7006659 & 4.94 \\
\hline 2015 & 9150310 & 9684951 & 0.33 \\
\hline 2016 & 4708450 & 9603550 & 0.49 \\
\hline
\end{tabular}

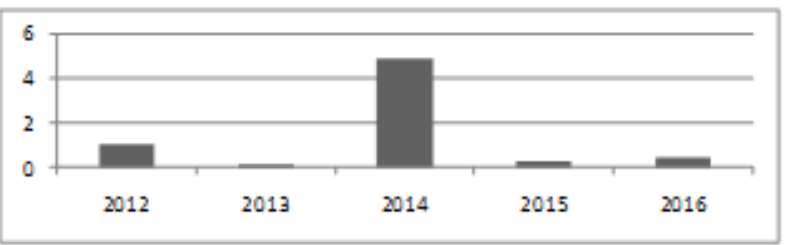

Fig:3 INVENTORY TO CURRE NT ASSET RATIO

\section{INFERENCE}

From the above table it can be inferred that the company's Inventory to Current Asset Ratio in the year 2012 to 2016. There is a fluctuating in this ratio. The highest ratio is on 201, 0.94 and get decreases and finally comes to 0.49 . [19],[21],[23]

\section{TABLE :8 GROSS PROFIT RATIO}




\begin{tabular}{|l|l|l|l|}
\hline YEAR & $\begin{array}{l}\text { GROSS PROFIT } \\
\text { R. }\end{array}$ & $\begin{array}{l}\text { CURRENT } \\
\text { ASSETS } \\
\text { Rs. }\end{array}$ & RATIO \\
\hline 2012 & 3753500 & 5465300 & 0.68 \\
\hline 2013 & 4172000 & 6204638 & 0.09 \\
\hline 2014 & 5509950 & 7006659 & 0.70 \\
\hline 2015 & 6793055 & 9684951 & 0.24 \\
\hline 2016 & 8215230 & 9603550 & 0.86 \\
\hline
\end{tabular}

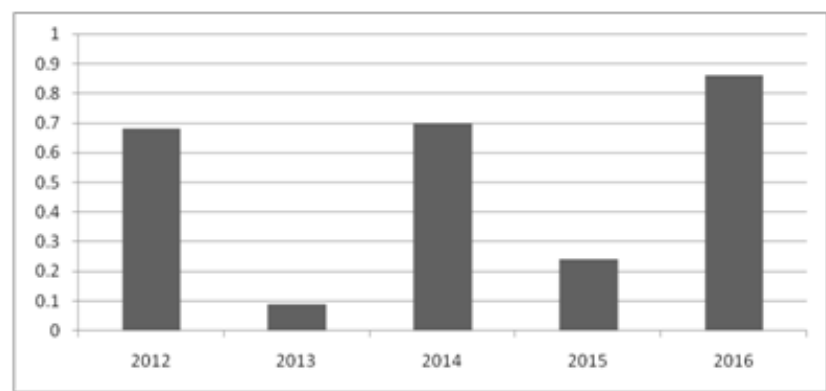

Fig:4 GROSS PROFIT RATIO

\section{RESULTS}

In the time of 2012, 2013 and 2014 shows increment in Working Capital. This demonstrates the organization has capacity of installment of momentary Liability. [20],[ 22], [24]

- The fixed resources proportion demonstrates that the working capital of this organization is subsidized by long haul finances which show proficient supports the executives.

- The Short - term Liquidity and long- term Liquidity position of the worry were concentrated to assess the Working Capital of the worry. During the examination time frame 2012 to 2016 the present proportion of the worry shifted from 8.63 to 2.21.But 2014 - 2015 is fluctuated from 0.77 to 1.80 . This was significantly less than the endorsed of $2: 1$. The induction is that the Current Liability may not be effectively met out of Current Asset by the Company. [25],[27],[29]

- The Quick proportion of the worry during the period 2012 - 2016 the examination is shifted from 7.22 to 1.67. Which was a lot more prominent than the endorsed standard of 1:1.So the organization Liquidity level is agreeable. [26],[28],[30]

- In Trend investigation the Cash \&Bank Balance have been expanded from 2012 to 2016.So it demonstrates the Cash position of the organization is great.

\section{DISCUSSION}

The organization is a benefit looking for one; it needs to submit the majority of its assets to accomplish its objective. To accomplish this, benefit, liquidity and dissolvability position a vital components to be checked cautiously, in this way the exchange off can be come to

- This organization's capacity to meet its present commitments is palatable however it doesn't meet the traditional standard. This organization keeps up current liabilities more than the measure of current resources which must be seen truly and improvement of this proportion is required to accomplish the ideal level. [31],[33],[32]

- Stock Turnover Ratio ought to be kept up at the constantlevel.

- The Cash and Bank Balances of the organization is great.

- Using pattern examination it tends to be recommended that the fixed resources bend shows unfaltering upward heading much than the present resources bend, which empower us to comprehend the organization's assets are dumped in fixed state, it's anything but a great condition to the organization fixed resource.

\section{CONCLUSION}

The present examination uncovers that the liquidity position of this organization is nearly great as it approaches the standard standards all through the time of study. All in all, it very well may be reasoned that the organization's general hazard assessment procedure isn't at wanted level and the creator has made the practical suggestion for the improvement in operational and administrative proficiency of the organization as to keep up and increment further by powerful use and control of the considerable number of advantages.

\section{REFERENCES}

1. G BharthVajan R., Ramachandran S.,Psychographic dimensions of training,2016,International Journal of Pharmacy and Technology,V-8,I-4,P-23727-23729

2. Balakrishnan P., Bharthvajan R.,A study on human resource planning in hospitals in Chennai City,2014,International Journal of Applied Engineering Research,V-9,I-22,P-7503-7507

3. Priyadarsini P., Bharthvajan R.,Role of emotional intelligence training programme in reducing the stress of the nurses,2014,International Journal of Applied Engineering Research,V-9,I-22,P-7411-7421

4. Kerinab Beenu G., Bharthvajan R.,Empirical analysis on the cosmetic buying behavior of young women in South India,2014,International Journal of Applied Engineering Research,V-9,I-22,P-7361-7366

5. Balakrishnan P., Bharthvajan R.,Whistling in the wind,2014,International Journal of Applied Engineering Research,V-9,I-22,P-7586-7593

6. Krishnan B., Peter M.,Health hazards of Indian Bpo employee-an alarming issue,2014,International Journal of Applied Engineering Research,V-9,I-22,P-7336-7341

7. Kerinab Beenu G.H., Peter M.,Role of insurance in economic development,2014,International Journal of Applied Engineering Research,V-9,I-22,P-7532-7539

8. Balakrishnan P., Peter M., Priyadarsini P.,Efficiency of safety measures for wellbeing of employees in manufacturing industry,2014,International Journal of Applied Engineering Research,V-9,I-22,P-7376-7382

9. Anbarasi M., Praveen Kumar S.,Online sales promotions of herbal products and its effectiveness towards tanisha.com,2019, Indian Journal of Public Health Research and Development,V-10,I-1,P-195-200

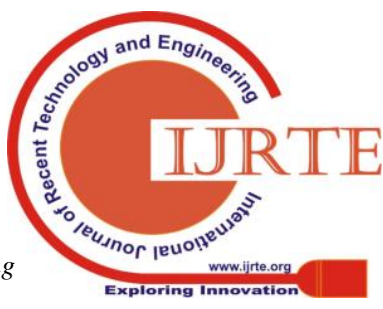


10. Anbarasi M., Praveen Kumar S.,Various online marketing and promotions strategies to improve the validation towards the organic products in the pharmaceutical sectors,2019,Indian Journal of Public Health Research and Development,V-10,I-1,P-263-269

11. Loganathan R., Praveen Kumar S.,Grievance handling a key factor for solving issues of employees in an organization,2014,International Journal of Applied Engineering Research,V-9,I-22,P-7483-7491

12. Loganathan R., Praveen Kumar S.,Study on preference of private label brands in super and Hypermarkets,2014,International Journal of Applied Engineering Research,V-9,I-22,P-7327-7335

13. Smitha M., Praveen Kumar S.,Understanding stress and its managementamong the nurses in Chennai city,2014,International Journal of Applied Engineering Research,V-9,I-22,P-7560-7565

14. Kerinab Beenu G.H., Praveen Kumar S.,A study on the investment behavior of Chennai investors in mutual fund schemes,2014,International Journal of Applied Engineering Research,V-9,I-22,P-7520-7525

15. Loganathan R., Praveen Kumar S.,Retention strategies key for organizational productivity,2014,International Journal of Applied Engineering Research,V-9,I-22,P-7443-7447

16. Pavithra J., Ganesan M., Brindha G.,State wise analysis of microfinance sector in India,2016,International Journal of Pharmacy and Technology,V-8,I-4,P-23417-23432

17. Pavithra J., Ganesan M.,A comparative study on microfinance in India and abroad,2016,International Journal of Applied Business and Economic Research,V-14,I-8,P-5471-5476

18. Pavithra J., Ganesan M.,A study on awareness and impact of micro-financial schemes,2016,International Journal of Applied Business and Economic Research,V-14,I-8,P-5449-5460

19. Senthilmurugan P., Pavithra J.,Consumer preference towards organised retailing with reference to Big Bazaar,2014,International Journal of Applied Engineering Research,V-9,I-22,P-7469-7475

20. Senthilmurugan P., Pavithra J.,Implication of social media marketing in growing healthcare industry,2014,International Journal of Applied Engineering Research,V-9,I-22,P-7448-7456

21. Loganathan R., Pavithra J.,Consumer perception towards private label brand over other brands in super markets and hypermarkets,2014,International Journal of Applied Engineering Research,V-9,I-22,P-7355-7360

22. Kerinab Beenu G., Pavithra J.,Tradeâ€"off between liquidity and profitability in logistics industry,2014,International Journal of Applied Engineering Research,V-9,I-22,P-7398-7401

23. Kerinab Beenu G., Pavithra J.,A study on the prospective consumerâ $€^{\mathrm{TM}_{\mathrm{S}}}$ perception towards utility cars in Chennai city,2014,International Journal of Applied Engineering Research,V-9,I-22,P-7526-7531

24. Pavithra J., Dilli Babu P., Ambuli T.V.,A study on budgetary control at Maruti Service Masters, Chennai,2014,International Journal of Applied Business and Economic Research,V-12,I-2,P-151-161

25. Pavithra J., Dilli Babu P., Ambuli T.V.,A study on customer satisfaction of retro Garments Pvt Ltd, Chennai,2014,International Journal of Applied Business and Economic Research,V-12,I-2,P-381-391

26. Kerinab Beenu G.H., Pavithra J., Senthilmurugan P.,A study on the influence of promotional activities for TATA ARIA among consumers in Chennai,2014,International Journal of Applied Engineering Research,V-9,I-22,P-7572-7578

27. Vijayaragavan S.P.,An investigative expert that's general FBG sensors,International Journal of Mechanical Engineering and Technology,V-8,I-8,PP-1500-1505,Y-2017

28. Vijayaragavan S.P.,Equalization routing protocol for Wi-Fi sensor strategy,International Journal of Mechanical Engineering and Technology,V-8,I-8,PP-1662-1666,Y-2017

29. Karthik B., Kiran Kumar T.V.U., Vijayaragavan P., Bharath Kumaran E.,Design of a digital PLL using $0.35 \hat{\mathrm{I}}^{1 / 4 \mathrm{~m}}$ CMOS technology,Middle East Journal of Scientific Research,V-18,I-12,PP-1803-1806,Y-2013

30. Kanniga E., Selvaramarathnam K., Sundararajan M.,Kandigital bike operating system,Middle - East Journal of Scientific Research,V

31. Jasmin M., Vigneshwaran T., Beulah Hemalatha S.,Design of power aware on chip embedded memory based FSM encoding in FPGA,International Journal of Applied Engineering Research,V-10,I-2,PP-4487-4496,Y-2015

32. Jasmin M.,Optimization techniques for low power VLSI circuits,Middle East Journal of Scientific Research,V-20,I-9,PP-1082-1087,Y-2014

33. Jasmin M., Vigneswaran T.,Fuzzy controller for error control of on - Chip communication,2017 International Conference on Algorithms, Methodology, Models and Applications in Emerging Technologies, ICAMMAET 2017,V-2017-January,I-,PP-1-5,Y-2017

\section{AUTHORS PROFILE}

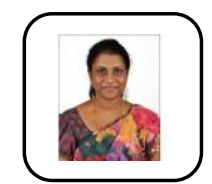

Magdalene Peter,Assistant Professor, Department of MBA, Bharath Institute of Higher Education and Research, Tamilnadu, India

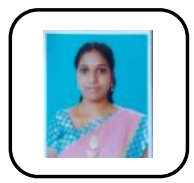

Dr.S.Fabiyola Kavitha, Associate Professor Department of MBA, Bharath Institute of Higher Education and Research, Tamilnadu, India. 